\title{
TERAPI METHOTREXATE PADA PASIEN DENGAN VASKULOPATI LIVEDOID
}

\author{
Sekar Puspita Lilasari ${ }^{\star 凶}$, Herwinda Brahmanti ${ }^{\star}$, Diah Prabawati Retnani**
}

\begin{abstract}
Abstrak
Penyakit vaskulopati livedoid (VL) adalah penyakit hialinisasi vaskuler yang jarang terjadi dan ditandai dengan ulkus rekuren, kronik, pada ekstremitas bawah serta livedoid reticularis dan atrophie blanche. Patogenesis penyakit belum jelas sehingga belum ada konsensus terapi untuk VL. Methotrexate suatu bahan imunosupresan merupakan salah satu modalitas terapi untuk vaskulitis. Dilaporkan satu kasus lakilaki usia 21 tahun dengan adanya luka yang nyeri dan berulang sejak 15 tahun lalu. Luka dapat sembuh sendiri dan meninggalkan bercak kecoklatan disertai bercak putih yang mengkilat. Tidak ada penyakit penyerta sistemik lain. Pemeriksaan dermatologik pada kedua cruris dan kedua dorsum pedis didapatkan ulkus multipel, bentuk bulat dan ireguler, batas tegas, disertai dengan livedo reticularis dan atrophie blanche. Terapi awal yang diberikan adalah metilprednisolon $1 \times 16 \mathrm{mg}$ per hari per oral namun dalam 2 minggu terjadi rekurensi berupa 6 ulkus baru. Kemudian diberikan methotrexate $15 \mathrm{mg} / \mathrm{minggu}$ per oral. Dengan pemberian methotrexate selama 2 minggu didapatkan perbaikan dibanding sebelumnya yaitu hanya 2 ulkus baru yang muncul. Disimpulkan Methotrexate dapat digunakan sebagai terapi alternatif pada vaskulopati livedoid, namun follow-up lebih lanjut tetap diperlukan untuk mengetahui rekurensi.
\end{abstract}

Kata Kunci: methotrexate, vaskulitis, vaskulopati livedoid (VL)

\section{METHOTREXATE IN LIVEDOIDVASKULOPATHY PATIENTS}

\begin{abstract}
Livedoid vasculopathy (LV) is a rare hyalinizing vascular disease characterized by painful chronic recurrent ulcers at lower extremities accompanied with livedoid reticularis and atrophie blanche. The pathogenesis is not clear yet, so there is no consensus therapy for LV. Methotrexate is one of immunosuppressant agent of modalities therapy for vasculitis. A case of 21 years-old man with painful and recurrent wound since 15 years ago. Wound was self-limited and then appeared brown patch with pearly white patch. No other comorbidities conditions. Dermatological examination at both cruris and both dorsal pedis showed multiple ulcers, round to irregular shape, sharply edge, with livedo reticularis and atrophie blanche. It was given methylprednisolone 1x16 mg per day per oral as initial therapy, but have appeared 6 six of new ulcers after 2 weeks of therapy. Then, it was treated with methotrexate $15 \mathrm{mg} / \mathrm{week}$ per oral. Clinical improvement achieved after 2 weeks given with methotrexate based on only 2 new ulcers reappeared. Accordingly, methotrexate (MTX) could be an alternative treatment for livedoid vasculopathy(LV), but further follow up is still needed to determine its recurrence.
\end{abstract}

Keywords: livedoid vasculopathy (LV), methotrexate, vasculitis.

* Dep. IImu Kesehatan Kulit dan Kelamin, Fakultas Kedokteran Universitas Brawijaya - RSSA, Malang

${ }^{* \star}$ Dep. Patologi Anatomi, Fakultas Kedokteran Universitas Brawijaya

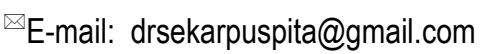




\section{Pendahuluan}

Vaskulopati livedoid (VL) atau yang dikenal juga sebagai vaskulitis livedoid, vaskulitis livedo, dan atrophie blanche adalah penyakit kulit ulkus yang nyeri rekuren, kronik, pada ekstremitas bawah yang disertai dengan livedoid reticularis (livedo racemosa) yang sering berwarna ungu gelap. ${ }^{1}$ Vaskulopati livedoid terutama terjadi wanita daripada laki-laki dengan $3: 1$, dapat muncul pada usia berapapun namun paling sering muncul antara usia 15-50 tahun dengan usia rata-rata adalah 32 tahun. ${ }^{2,3}$

Patogenesis VL masih belum diketahui dengan jelas. Beberapa kondisi yang berhubungan dengan $V L$ adalah seperti insufisiensi kronik vena, penyakit autoimun jaringan ikat, trombofilia turunan maupun didapat, neoplasma, dan idiopatik. ${ }^{4,5}$

Penyakit VL merupakan penyakit yang jarang terjadi, sehingga konsensus terapi yang terbaik pada penyakit ini masih belum ada. Pendekatan terapi pada VL bervariasi dengan respons yang juga bervariasi. Data literatur tentang terapi VL juga sangat terbatas dan terutama berdasarkan pada serial kasus ataupun suatu laporan kasus. Penting sekali menginvestigasi kemungkinan beberapa penyebab yang berhubungan dengan VL untuk menentukan terapi. ${ }^{4,6,7}$

Methotrexate merupakan salah satu modalitas terapi berupa imunosupresan pada kasus vaskulitis. Investigasi awal bahwa methotrexate digunakan sebagai terapi vaskulitis adalah berdasarkan mekanisme aksinya dan hasil dari beberapa laporan kasus. 3,7 Sepanjang pengetahuan penulis belum ada laporan kasus vaskulitis livedoid yang menggunakan terapi dengan methotrexate. Kami melaporkan satu kasus vaskulopati livedoid pada laki-laki yang muncul sejak usia 6 tahun dengan terapi methotrexate.

\section{Laporan Kasus}

Seorang laki-laki berusia 21 tahun datang ke Poli Kulit dan Kelamin RSUD dr. Saiful Anwar Malang dengan keluhan lukaluka di kedua tungkai dan kaki yang terasa nyeri kambuh-kambuhan sejak 15 tahun yang lalu. Awalnya berupa bercak kecoklatan kemudian menjadi bintil lalu menjadi luka dan luka tersebut dapat sembuh sendiri lalu meninggalkan bekas berupa bercak putih dan coklat. Pada awalnya luka berjumlah sedikit hanya muncul di kedua kaki kemudian dalam 5 tahun terakhir, luka dirasakan semakin banyak muncul sampai ke kedua tungkai. Luka juga disertai nanah. Rasa nyeri terutama saat berjalan hanya dirasakan apabila terdapat luka.

Tidak ada keluhan kulit serupa di bagian tubuh lain berupa nyeri ataupun bengkak pada sendi, demam, kencing seperti teh, rasa silau berlebihan terhadap sinar matahari, nyeri dada, sesak nafas serta penyakit keganasan yang diderita. Tidak ada penyakit sama yang dialami oleh keluarga. Pasien belum menikah dan bekerja sebagai tukang bangunan. Apabila penyakitnya kambuh, pasien tidak dapat melakukan pekerjaannya.

Selama 15 tahun, pasien hanya satu kali berobat ke dokter spesialis kulit pada 10 tahun yang lalu, diberi obat salep (lupa namanya), ada perbaikan namun kambuh lagi. Satu bulan yang lalu pasien mulai berobat ke Poli Kulit dan Kelamin RSUD dr. Saiful Anwar Malang, mendapatkan pengobatan metilprednisolon 1x $24 \mathrm{mg}$ per oral selama 2 minggu kemudian dilanjutkan metilprednisolon $1 \mathrm{x}$ sehari $16 \mathrm{mg}$ selama 2 minggu karena ada perbaikan. Namun 2 minggu selanjutnya dosis metilprednisolon dinaikkan menjadi 1x $24 \mathrm{mg}$ kembali oleh karena muncul luka baru.

Pemeriksaan dermatologik pada kedua regio cruris dan kedua dorsum 
pedisdidapatkan ulkus multipel, bentuk bulat dan ireguler, batas tegas, disertai dengan livedo reticularis dan terdapat atrophie blanche serta tidak tampak adanya telangictasis.Pada kedua plantar didapatkan purpura non-palpable, multipel, berwarna merah-keunguan, bentuk bulat, batas tegas. Rasa nyeri yang dirasakan diukur dengan visual analog scale (VAS) yaitu 6.

Pemeriksaan fisik menunjukkan dalam batas normal. Tanda vital dalam batas normal, tekanan darah $110 / 70 \mathrm{mmHg}$, temperatur aksilla $36,7^{\circ} \mathrm{C}$, nadi $88 \mathrm{x} / \mathrm{menit}$, laju nafas 20x/menit. Pemeriksaan jantung, paru dan abdomen dalam batas normal. Tidak didapatkan pembesaran kelenjar getah bening kedua inguinal, tidak didapatkan oedem pada kedua tungkai dan kaki, akral hangat.
Pemeriksaan Gram pada ulkus didapatkan sel radang polimorfonuklear (PMN), namun tidak didapatkan bakteri. Pemeriksaan laboratorium didapatkan peningkatan eosinofil 6,8\% (0-4), hasil darah lengkap lainnya, fungsi hati, fungsi ginjal dan gula darah sewaktu dalam batas normal.

Pemeriksaan histopatologik yang diambil dari biopsi antara ulkus dan kulit normal sekitarnya didapatkan sebagian epidermis yang tidak intak, namun epidermis yang intak dalam batas normal, pada dermis didapatkan sebukan sel radang polimorfonuklear, tidak tampak adanya oklusi pada pembuluh darah, terdapat destruksi vaskuler, ekstravasasi eritrosit, nekrosis fibrinoid, infiltrasi sel radang PMN pada intramural dan perivaskuler, debris neutrofil (leukositoklastik) pada perivaskuler.

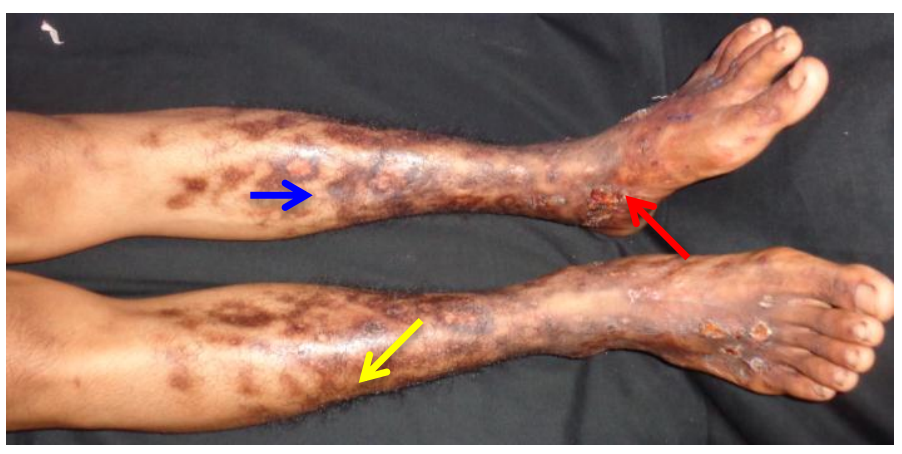

Gambar 1. Ulkus berjumlah 13, bentuk bulat dan ireguler, batas tegas, tepi meninggi, dasar bersih, sebagian tertutup krusta kehitaman ( $)$, disertai dengan livedo reticularis ( ) dan terdapat atrophie blanche (

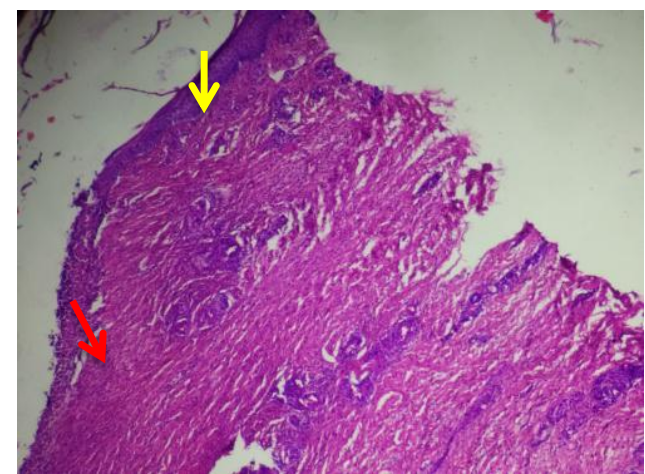

Gambar 2. Sebagian epidermis tidak intak $(7)$. Sebagian epidermis intak dan dalam batas normal ( ) (perbesaran 400x, Hematoksilin-Eosin) 


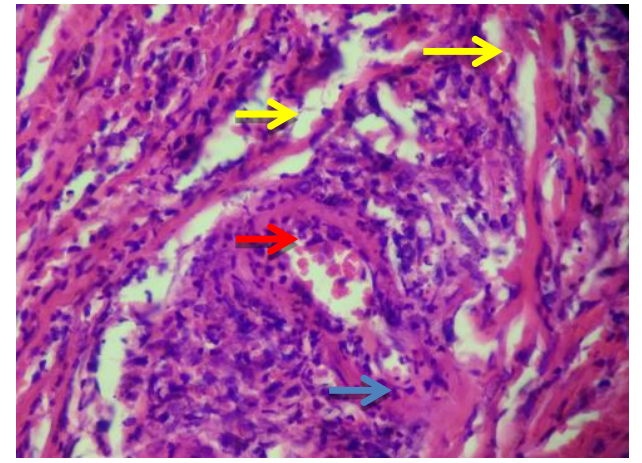

Gambar 3. Dermis: Infiltrasi PMN intramural dan perivaskuler (7). Ekstravasasi eritrosit (" ). Debri neutrofil perivaskuler ( $)$ (perbesaran 1000x, Hematoksilin-Eosin)

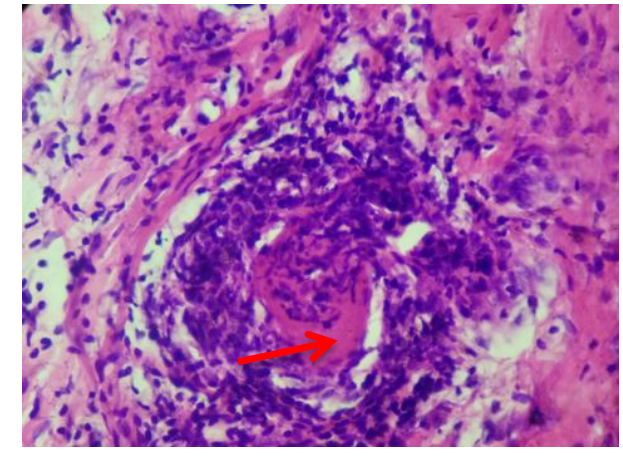

Gambar 4. Dermis: Nekrosis fibrinoid ( $\nearrow$ ). (perbesaran 1000x, Hematoksilin-Eosin)

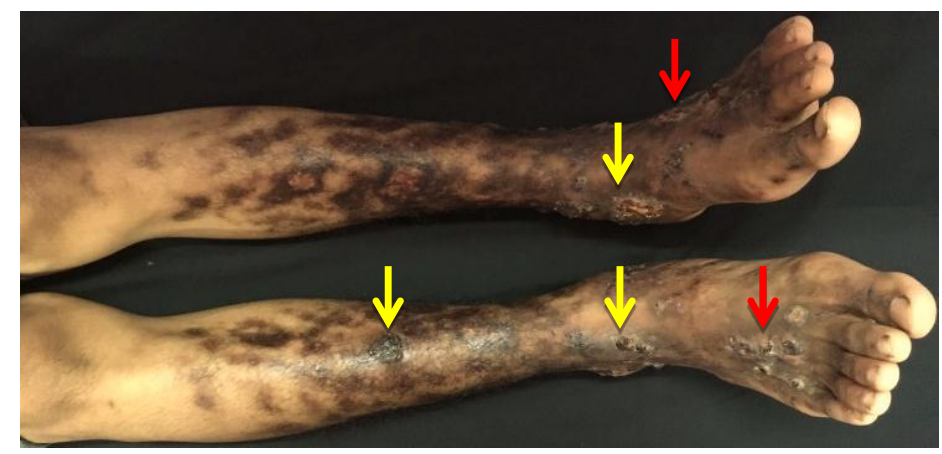

Gambar 5. Hasilfollow-up setelah 2 minggu terapi metilprednisolon, loratadin, asam mefenamat. Ulkus baru $\leftrightarrow$ j, ulkus lama yang mengalami perbaikan $\leadsto$ )

Pemeriksaan faal hemostasis berupa waktu perdarahan, waktu pembekuan, (PPT), International Normalized Ratio (INR) normal. Namun ada peningkatan sedikit pada Activated Partial Thromboplastin Time (APTT) yaitu 35,40 detik (normal: 24,6 - 30,6 detik). Hasil elektroforesis protein dalam batas normal.

Pasien dikonsulkan ke Departemen Jantung dan Pembuluh Darah untuk mengevaluasi apakah ada kelainan vaskuler pada pembuluh darah tungkai. Hasil Ultrasonografi Doppler pada kedua tungkai tidak ditemukan adanya kelainan vaskuler baik insufisiensi vena kronik ataupun penyakit arteri perifer. Ankle Brachial Index (ABI) tungkai kanan 1,08, tungkai kiri 1,01, yang berarti dalam batas normal. Belum ada indikasi pemberian antikoagulan maupun antitrombotik pada pasien ini.

Berdasarkan anamnesis, pemeriksaan fisik serta pemeriksaan penunjang pasien didiagnosis vaskulopati livedoid dengan kemungkinan penyebab idiopatik. Oleh karena itu, dilanjutkan terapi imunosupresan berupa steroid. Pasien diterapi dengan metilprednisolon $1 \mathrm{x}$ sehari $16 \mathrm{mg}$ per oral selama 2 minggu ditambah dengan loratadin $1 \mathrm{x}$ sehari $10 \mathrm{mg}$, asam mefenamat $3 \mathrm{x}$ sehari serta rawat luka.

Hasil follow up setelah 2 minggu terapi dengan metilprednisolon, loratadin serta asam mefenamat, didapatkan 6 lesi ulkus yang baru (Gambar 5) muncul disertai dengan nyeri (VAS=8). Selain itu didapatkan erupsi acneiformis pada punggung. 


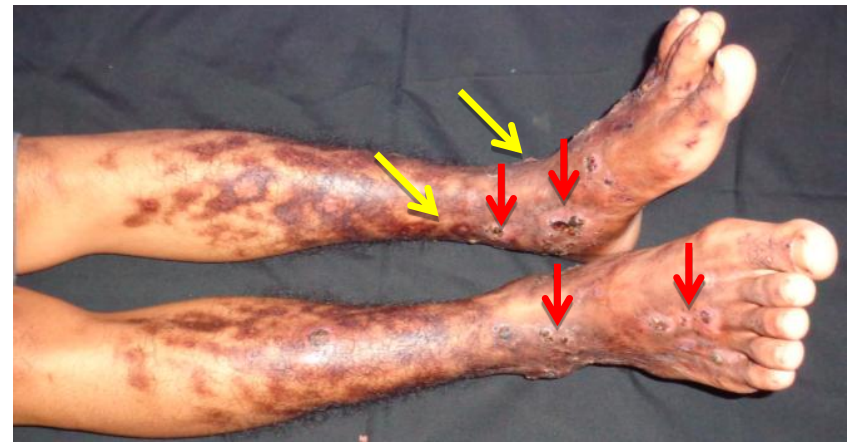

Gambar 6.Hasil follow-up setelah 2 minggu terapi dengan Methotrexate. Ulkus baru ( $\doteq$ ), ulkus lama mengalami perbaikan, tertutup krusta coklat-kehitaman (

Pemeriksaan Gram pada ulkus ditemukan sel radang polimorfonuklear dengan coccus Gram positif tersusun bergerombol. Pemeriksaan laboratorium darah lengkap, fungsi hati, fungsi ginjal, gula darah sewaktu dalam batas normal. Terdapat peningkatan leukosit $13.450 \mu \mathrm{L}$, laju endap darah $25 \mathrm{~mm} / \mathrm{jam}$ dan monosit $7,1 \%$ (normal: 2 - 5\%).

Terapi per oral diganti dengan methotrexate 15mg/minggu (Senin dan Pemeriksaan laboratorium darah lengkap, fungsi hati dan fungsi ginjal dalam batas normal. Terapi per oral tetap dilanjutkan methotrexate 15mg/minggu (Senin dan Selasa setiap 12 jam) selama 2 minggu ditambah dengan asam folat $1 \times 1 \mathrm{mg}$ (Kamis - Minggu).

\section{Pembahasan}

Etiopatogenesis yang berhubungan dengan vaskulopati livedoid adalah penyakit vena kronik, penyakit autoimun jaringan ikat (lupus eritematus sistemik, skleroderma, rheumatoid arthritis), trombofilia herediter (mutasi faktor $\mathrm{V}$, mutasi gen protrombin, mutasi pada promoter inhibitor-1 tissue plasminogen activator, defisiensi antitrombin, defisiensi protein $\mathrm{C}$, defisiensi protein $\mathrm{S}$ ), Trombofilia didapat (sindroma antifosfolipid, krioglobulin, kriofibrinogenemia, peningkatan homosistein), keganasan hematologik, keganasan organ padat, serta idiopatik. ${ }^{5}$
Selasa setiap 12 jam) selama 2 minggu ditambah dengan cefadroxil 2x $500 \mathrm{mg}$ per hari selama 5 hari dan asam folat $1 \times 1 \mathrm{mg}$ (Kamis - Minggu). Terapi topikal diberikan lotio Kumerfeldi $1 \mathrm{x}$ sehari pada punggung dan gentamisin krim $2 x$ sehari pada ulkus.

Hasil follow up setelah 2 minggu terapi dengan methotrexate didapatkan perbaikan terhadap ulkus, nyeri berkurang (VAS $=3$ ), muncul 2 ulkus baru namun langsung membaik dengan cepat.

Prevalensi vaskulopati livedoid pada populasi di Amerika Serikat adalah sekitar 1 kasus per 100.000 orang per tahun. Vaskulopati livedoid terutama terjadi wanita daripada laki-laki dengan rasio $3: 1$, dapat muncul pada usia berapapun namun paling sering muncul antara usia 15-50 tahun dengan usia rata-rata adalah 32 tahun., 3

Diagnosis VL yang akurat diperlukan data riwayat pasien, pemeriksaan fisik, histopatologi dan parameter laboratorium. Vaskulopati livedoid merupakan penyakit kulit yang kronik, rekuren dan nyeri, yang berupa lesi awal makula dan/atau papula lentikuler atau punctate berwarna keunguan pada tungkai bawah (sepertiga bawah tungkai, pergelangan kaki, dan kaki), sering progresif menjadi ulserasi yang secara lambat sembuh spontan dalam waktu beberapa minggu atau bulan, kemudian memberikan gambaran skar atrofi berwarna putih mengkilat (atrophie blanche), telangiektasis, pigmentasi kecoklatan serta 
livedo racemosa. 5,8 Pada kasus ini didapatkan keluhan ulkus yang nyeri, berulang dan dapat sembuh sendiri sejak usia 6 tahun (diderita selama 15 tahun) dan dari pemeriksaan dermatologik pada kedua regio cruris dan kedua dorsum pedis didapatkan ulkus multipel, bentuk bulat dan ireguler, batas tegas, disertai dengan livedo reticularis serta terdapat atrophie blanche yang sesuai dengan gambaran klinis livedoid vaskulopati.

Vaskulopati livedoid merupakan penyakit dengan patofisiologi yang belum jelas. Vaskulopati livedoid dapat merupakan keadaan primer maupun sekunder. Vaskulopati primer tidak berhubungan dengan adanya penyakit lain dan biasanya idiopatik. Vaskulopati sekunder biasanya berkaitan dengan trombofilia turunan (mutasi faktor $\mathrm{V}$ Leiden, mutasi gen protrombin) maupun didapat (defisiensi protein $\mathrm{C}$ dan/atau $S$, hiperhomosisteinemia), insufisiensi kronik vena, penyakit autoimun jaringan ikat (Lupus eritematosus sistemik), dan neoplasma. Oleh karena itu, penting untuk menggali riwayat pasien dan keluarga tentang keadaan hiperkoagulasi dan penyakit inflamasi atau autoimun lainnya.,2,9 Tidak didapatkan riwayat pasien yang terkait dengan keadaan hiperkoagulasi dan lupus eritematosus sistemik, serta tidak ada penyakit kulit serupa pada riwayat keluarga pada kasus ini.

Selain pemeriksaan fisik yang lengkap dibutuhkan pemeriksaan laboratorium berupa darah lengkap, tes koagulasi, petanda autoimun seperti anti-nuclear factor, anti-DNA antibody, dan sangat penting dilakukan ultrasonografi Doppler pada tungkai bawah dengan tujuan mengetahui adanya insufisiensi kronik vena. ${ }^{9}$ Pada pasien ini tidak terbukti adanya keadaan hiperkoagulasi dari data laboratorium faal hemostasis, platelet dan fungsi platelet. Hasil ultrasonografi Doppler pada tungkai bawah juga menunjukkan tidak adanya insufisiensi kronik vena, serta tidak didapatkan adanya penyakit arteri perifer.

Mekanisme patofisiologi pada VL bukan merupakan suatu vaskulitis primer namun suatu vaskulopati yang berupa proses oklusi vaskular akibat dari thrombosis pembuluh darah dermis kecil dan sedang, adanya perubahan keadaan inflamasi dapat ditemukan di lesi lanjut dan merupakan suatu keadaan sekunder. Jadi, gambaran histopatologi VL adalah adanya hialinisasi segmental, proliferasi endotel dan trombosis pada pembuluh darah atas dan tengah dermis tanpa adanya ciri khas vaskulitis yaitu infiltrat neutrofil pada dinding pembuluh darah dan nekrosis fibrinoid. , $11^{11}$

Pemeriksaan histopatologik pada kasus ini yang diambil dari biopsi antara ulkus dan kulit normal sekitarnya didapatkan sebagian epidermis yang tidak intak, namun epidermis yang intak dalam batas normal, pada dermis didapatkan sebukan sel radang polimorfonuklear, tidak tampak adanya oklusi pada pembuluh darah, terdapat destruksi vaskuler, ekstravasasi eritrosit, nekrosis fibrinoid, infiltrasi sel radang PMN pada intramural dan perivaskuler, debris neutrofil (leukositoklastik) pada perivaskuler. Sehingga memberikan gambaran suatu vaskulitis yang diduga merupakan vaskulitis sekunder. Hal ini sesuai pada beberapa kasus, dengan mekanisme yang dimediasi oleh respons imun yang dapat berakibat pada terjadinya kerusakan vaskuler, yang selanjutnya akan menjadi suatu proses vaskulitis pembuluh darah kecil. ${ }^{11}$

Oleh karena patogenesis yang belum jelas, tidak ada terapi tunggal yang efektif untuk kondisi penyakit ini. Pilihan terapi saat ini hanya berdasarkan suatu laporan kasus saja. Sebagian besar terapi bertujuan untuk memperbaiki manifestasi klinis dan mengurangi rasa nyeri.Terapi VL yang didapatkan dari literatur terdiri dari antiplatelet dan anikoagulan, agen fibrinolitik, vasodilator, fototerapi dengan PUVA, terapi 
oksigen hiperbarik, dan imunosupresan (kortikosteroid, siklosporin) serta immunoglobulin intravena. ${ }^{10}$

Methotrexate (MTX) memiliki beberapa efek supresi potensial, baik pada imunitas seluler maupun humoral. Selain itu, MTX memiliki aktivitas antiinflamasi yang berkaitan dengan metabolisme adenosine. MTX telah ditemukan meningkatkan akumulasi adenosine dan merilis adenosine dari fibroblast dan sel endotel sehingga mencegah adhesi neutrofil ke sel yang merupakan langkah penting dalam patogenesis vaskulitis. ${ }^{7}$

Menurut studi oleh Zeni $\mathrm{P}$ et al,meskipun patogenesis VL belum jelas, diduga $V L$ berkorelasi dengan penyakit kompleks imun dan secara histologik didapatkan adanya infiltrat sel inflamasi, namun perlu studi lanjut untuk hal ini. ${ }^{12}$ Sehingga imunosupresan dapat dimasukkan sebagai alternatif terapi. Sepanjang pengetahuan penulis, belum ada laporan kasus vaskulopati livedoid yang menggunakan terapi dengan MTX serta belum ada dosis terapi MTX terhadap vaskulopati livedoid. Namun telah disebutkan pada satu literatur bahwa MTX merupakan salah satu terapi untuk vaskulopati livedoid. Pada kasus ini digunakan dosis MTX sesuai dengan terapi pada vaskulitis. Dosis MTX pada vaskulitis adalah 15-25 mg per minggu dan perlu dihindari pada pasien dengan kelainan fungsi ginjal. 3,13

\section{Kesimpulan}

Telah dilaporkan satu kasus vaskulopati livedoid (VL) pada laki-laki yang diderita selama 15 tahun dan kambuhkambuhan. Diagnosis vaskulopati livedoid ditegakkan berdasarkan anamnesis, pemeriksaan fisik serta pemeriksaan penunjang. Akibat patogenesis yang belum jelas, maka belum ada konsensus terapi untuk vaskulopati livedoid. Pada kasus ini tidak didapatkan adanya keterkaitan dengan keadaan hiperkoagulasi, penyakit autoimun jaringan ikat, keganasan. Selain itu, dari hasil pemeriksaan histopatologik tidak didapatkan adanya trombosis pada vaskuler dermis. Terapi imunosupresan berupa methotrexate digunakan pada kasus ini dengan dosis $15 \mathrm{mg} /$ minggu selama 2 minggu dan didapatkan perbaikan dengan indikator munculnya ulkus baru menjadi lebih sedikit. Namun, follow-up lebih lanjut tetap diperlukan untuk mengetahui rekurensi. Dari kasus tersebut dapat disimpulkan bahwa methotrexate (MTX) dapat digunakan sebagai alternatif terapi pada vaskulopati livedoid.

\section{Daftar Pustaka}

1. Soter NA. Cutaneous Necrotizing Venulitis. Dalam: Goldsmith LA, Katz SI, Gilshrest BA, Paller AS, Leffel DA, Wolff K, (Editor). Fitzpatrick's Dermatology in General Medicine. Edisi ke-8. New York: Mc-Graw-Hill. 2012. 163: 2003-2012.

2. Provenza JR, Pedri LE, Provenza GM. Livedoid Vasculopathy. Revista Brasileira de Reumatologia. 2016; 272:1-4.

3. Benhadou F, Wautrecht JC. Livedo(id) Vasculitis. Dalam: Teot L, Meaume S, Akita S, Ennis WJ, del Marmol V, Editor. Skin Necrosis. Wien Heidelberg: Springer. 2015. 26: 161-163.

4. Bollmann PW, Shimada AK, Michalany NS, Manhani ARAB, del Giglio A. Livedoid Vasculopathy: Fast Involution after Anticoagulant and Hyperbaric Oxygen Therapy. Einstein. 2011; 9(2 pt 1):212-215.

5. Criado PR, Sotto MN, Aoki V, Vasconcellos C, Rivitti EA, Valente NYS, et al. Livedoid Vasculopathy: an Intriguing Cutaneous Disease. Anais Brasileiros de Dermatologia. 2011; 
86(3):961-977.

6. Hesse G, Kutzner H. Therapeutic Use of Low Molecular Weight Heparin for Capillaritis Alba. Phlebologie. 2008. 37:259-65.

7. Langford CA, Sneller MC, Hoffman GS. Methotrexate Use in Systemic Vasculitis.Rheumatic Disease Clinics of North America. 1997. 23(4):841-853.

8. Hairston BR, Davis MDP, Pittelkow MR, Ahmed I, Livedoid Vasculopathy: Further Evidence for Procoagulant Pathogenesis. Archives of Dermatology. 2006; 142:1413-8.

9. Khenifer S, Thomas L, Balme B, Dalle S. Livedoid Vasculopathy: Thrombotic or Inflammatory Disease. Clinical and Experimental Dermatology. 2010; 35:693-8.
10. Gonzalez-Santiago TM, Davis MDP. Update of Management of Connective Tissue Diseases: Livedoid Vasculopathy. Dermatologic Therapy. 2012;25:183-94.

11. Okada E, Nagai Y, Ishikawa O. A Case of Widespread Livedoid Vasculopathy with Pain but No Systemic Symptoms. Acta Dermato-venereologica. 2008; 88:298-299.

12. Zeni $P$, Finger $E$, Scheinberg $M$. Successful Use of Rituximab in A Patient with Recalcitrant Livedoid Vasculopathy. Ann Rheum Dis. 2008; 67:1055-1056.

13. Luqmani RA. State of the Art in the Treatment of Systemic Vasculitides. Frontiers in immunology. 2014; 5:471. 